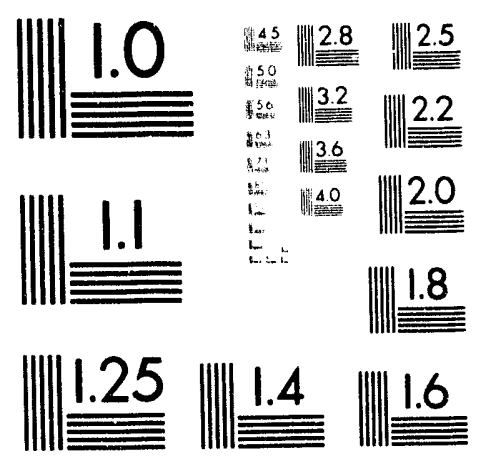



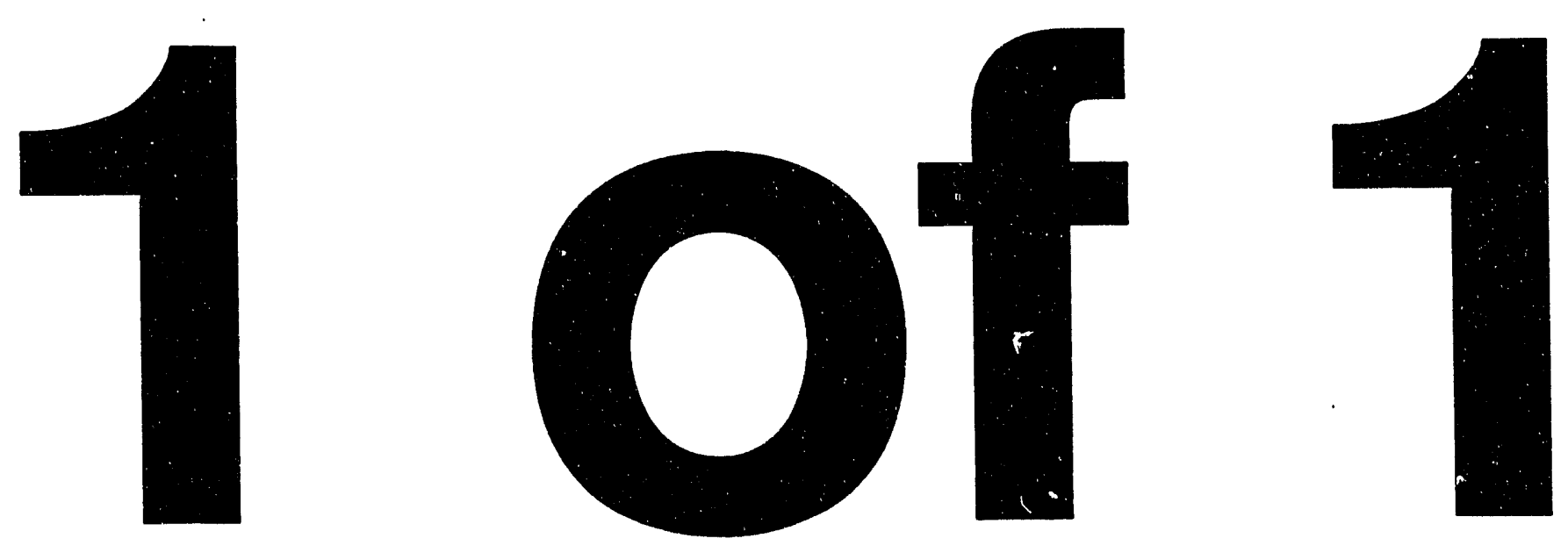


\title{
Assessment of the Organizational Structure and Services of DOE National Laboratory Libraries
}

\author{
Kathy Dieden
}

San Jose State University

May 18, 1993

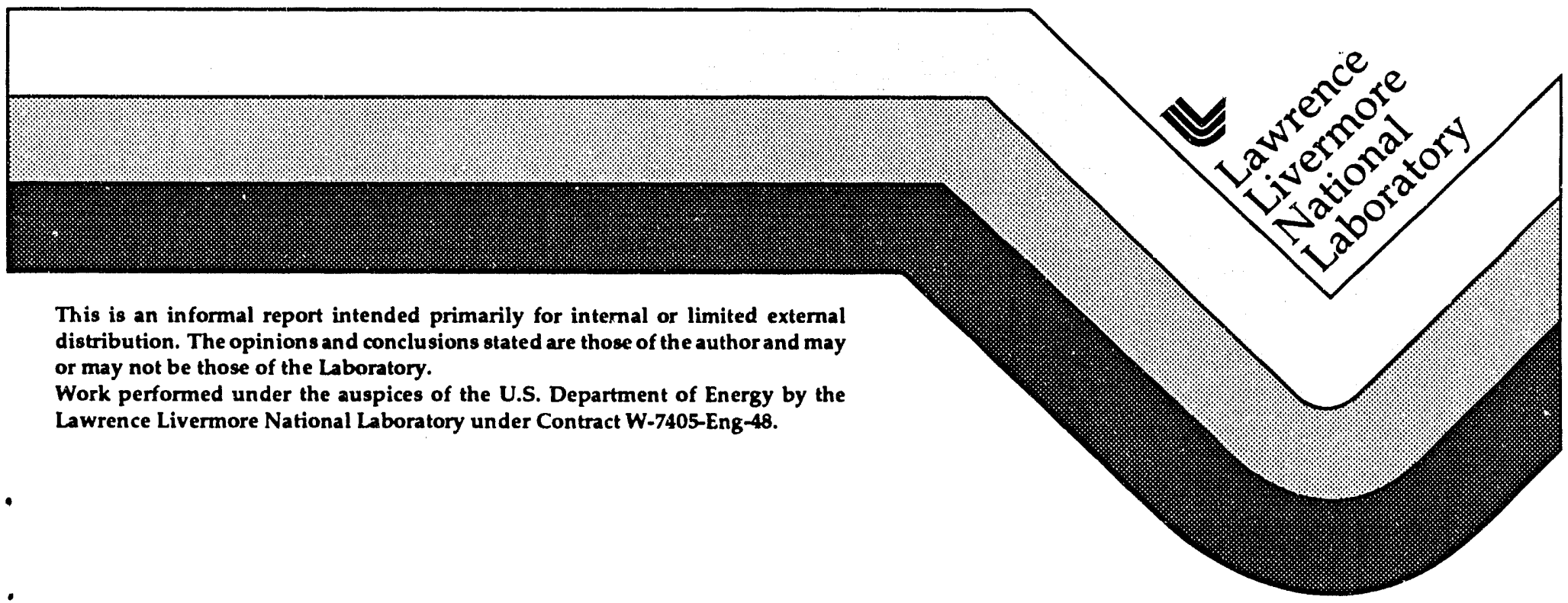




\section{DISCLAIMER}

This document was prepared as an account of work sponsored by an agency of the United States Government. Neither the United States Government nor the University of California nor any of their employees, makes any warranty, express or implied, or assumes any legal liability or responsibility for the accuracy, completeness, or usefulness of any information, apparatus, product, or process disclosed, or represents that its use would not infringe privately owned rights. Reference herein to any specific commercial products, process, or service by trade name, trademark, manufactures, or otherwise, does not necessarily constitute or imply its endorsement, recommendation, or favoring by the United States Government or the University of California. The views and opinions of authors expressed herein do not necessarily state or reflect those of the United States Government or the University of California, and shall not be used for advertising or product endorsement purposes.

This report has been reproduced directly from the best available copy.

Available to DOE and DOE contractors from the Office of Scientific and Technical Information P.O. Box 62, Oak Ridge, TN 37831

Prices a vailable from (615) 576-8401, FTS 626-8401

A vailable to the public from the National Technical Information Service US. Department of Commerce 5285 Port Royal Rd., Springfield, VA 2216 


\title{
Assessment of the Organizational Structure and Services of DOE National Laboratory Libraries
}

\author{
Kathy Dieden \\ San Jose State University \\ May 18, 1993
}

This work was done in partial fulfillment of the requirements for the Special Libraries course (LIBR 231) at San Jose State University.

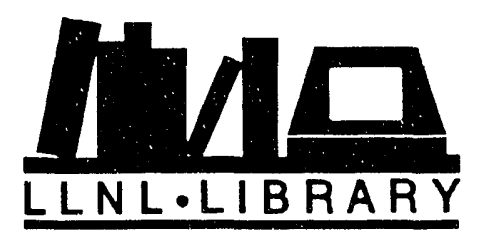




\section{Executive Summary}

The national laborato: $\because$ under the aegis of the Department of Energy, have been the institutional heart of research and development in the nuclear age. Their mission, in its broadest sense, has been the development and creation of nuclear weapons. The surety of that mission is in doubt. The reconfiguration of Eastern Europe, a result, in part, of the break-up of the Soviet Union and the collapse of Communism, the unrealized promise of a peace dividend, and a Democratic President in the White House, leaves the national laboratories, at least temporarily, rudderless, like ships afloat in uncharted waters.

The daily newspaper is rife with stories of what the new mission or missions of the laboratories might be; environmental and biomedical research being cited most often, followed by joint ventures between the laboratories and private industry for a number of peacetime applications. The new missions are, as yet, unformulated and unclear. What is clear is that research and development in the nuclear industry is in flux. In this work/study project, I looked at the role of libraries and information in the national laboratories and how librarians are serving the needs of the scientific community.

The work/study project is limited to the collection, and some discursive analysis, of the information. The observations are based upon telephone interviews with librarians in nine national laboratories and several in-person interviews with two librarians at Lawrence Livermore. The work/study project attempts to evaluate library services and examines the organization charts of each facility and the organization structure. Studying the role information services plays in the organization is one indication of how the institution might value information - its services and management. 


\section{Introduction}

This fieldwork assignment was created to assess the library and information services at the National Laboratories and to understand their organizational structures and the role of the library within those structures. My goal was to collect the data and, if time permits, to evaluate the data and make appropriate recommendations for improving the quality of service at Lawrence Livermore National Laboratory Library. The objectives are outlined below.

\section{Objectives}

- To develop a questionnaire which will be used in the reference interview.

- To contact a knowledgeable staff person at each facility and collect the information services data from that person.

- To identify innovative and unique services.

- To identify non-traditional methods of delivering information services to the scientific clientele.

- To obtain any user feedback on the services provided.

- To identify the organization structure of each of the National laboratories and to determine the role of the library within those structures.

\section{Library Services}

\section{Hours of Operation}

Many libraries are open twenty-four hours a day. However, the library is staffed only during regular working hours five days a week. One library requires that after-hours access be arranged by consulting the librarian (Lawrence Berkeley).

\section{Services}

At a minimum the national laboratories' libraries provide the following services: reference verification and literature searches, online and print; preprints and technical reports; acquisitions; current awareness; standards and specifications; CD-ROM products; ordering of publications; translation brokering; interlibrary loan; photocopying; document delivery; and end-user training.

Many of the libraries provide other services such as: networking of CDROMs over the LAN; public access to the library's unclassified collection through 
an online catalog like the University of California's Melvyl; creation of in-house databases; evaluation of software products; and records management.

Several of the libraries provide their services in a unique way. Some Lawrence Livermore librarians are "matrixed" to a particular scientific project. This means that the librarian works with the research team for the life of the project. The librarian is an integral part of the team - its information specialist. The librarian attends project meetings and provides the information necessary to the success of the project. Because the information specialist is a valued member of the research team, the librarian is able to provide not only what is requested but is able to anticipate the scientists' needs. The collaboration between scientists and librarians led to widespread agreement in the Biomedical Sciences Division that "the librarian should not only act as a resource providing information services to the research staff but should also contribute knowledge and expertise to long-term information management." 1 (Moulik, Lai). Matrixed library specialists evaluate software and create databases essential to the projects research. The Golden Colorado facility provides a similar service to its scientists but the information specialists are contract librarians.

As a cost-saving measure the librarians at Los Alamos met with a research team composed of eighty-five scientists to reduce the number of journal subscriptions in their field. Earlier this year when the librarians warted to introduce a trial twenty-four hour a day EMail reference service, they decided to limit the service to the group of scientists who were part of the collection development team. Scientists will be able to EMail a reference request any time of the day or night and the staff reference librarian will answer the query as soon as possible on the next working day.

Lawrence Berkeley librarians provide high energy physics preprints daily or weekly via EMail.

National Renewal Energy Laboratory is considering publishing an alternative energy newsletter in conjunction with a private company.

Librarians at Sandia National Laboratory act as intermediaries between scientists and vendors to facilitate contract agreements for the utilization of specialized databases.

Nearly all the laboratories are attempting to network CD-ROMs. This requires standardization and is a slow, ongoing process. Most facilities are beginning to utilize the Internet as a resource. The national laboratories continue to liaison with business communities in hopes of creating joint research and development projects.

Some libraries and reading rooms are open to the public. 
Fees

While a number of laboratories recharge for online searches, rush orders, photocopying, and translation services, LLNL has the greatest number of recharges. In addition to those mentioned, LLNL charges for book, journal, and report acquisitions, interlibrary loans, branch library staffing, current awareness searches, and matrix information specialist services. Recharging for the matrix services enables the librarians to work with the scientists as a member of the scientific team. Without the ability to recharge the scientific project, LLNL would be unable to provide their clients with this valuable user service.

\section{Organizational Structure}

"For the Japanese, the statement that knowledge is power is not just a pious truism, it is a basic operating principle." 2 (Prusak and Matarazzo). In their study of eight major Japanese firms and how they value information and information management, Prusak and Matarazzo reached the following conclusions:

1. Japanese firms perceive their corporate libraries and information centers as an increasingly important resource.

2. Japanese executives place a tremendous value on information and view it as an essential cost of doing business.

3. The library information function operations are well designed to support the firm's objectives.

4. While information technology applications are highly valued in Japan, information management is not a subset of a technological function.

5. The management of the information function is rotated among all company managers; treating information functions equally with other key functions further demonstrates senior management's commitment to information management.

6. Japanese managers read. Many senior executives were seen reading in their corporate information centers and libraries.

Contrast this portrait of an information value laden business environment fostered by Japanese firms with Thomas Davenport's analysis of information management in American business firms. "Mariy of the efforts to create information-based organizations or even to implement significant information management have failed or are on a path to failure. Today, in fact, the information-based organization is largely a fantasy," 3 (Davenport). He concludes that companies fail to become information-based because their executives do not manage information politics. 
The national laboratories are information-intensive environments. We might expect that these research and development organizations would value information highly. We might also expect to find that the library and inform.tion managers exercise a considerable political influence within the organization. One method of assessing the importance of the information function within the laboratories is to review their organization charts and the role of their libraries within the organization structure. While the time constraints of this study do not allow for an in-depth analysis, I believe my preliminary conclusions reflect, in part, the value each organization places on its information function and to what extent the library and information services is politically powerful.

My preliminary analysis of the organizational structure of each national laboratory reviewed is described on the following pages. In a research driven organization, the most desirable reporting system for the library would be to report directly to its clients - the scientists. Only one national laboratory follows this model. It is the Superconducting Super Collider Laboratory, SSC. 


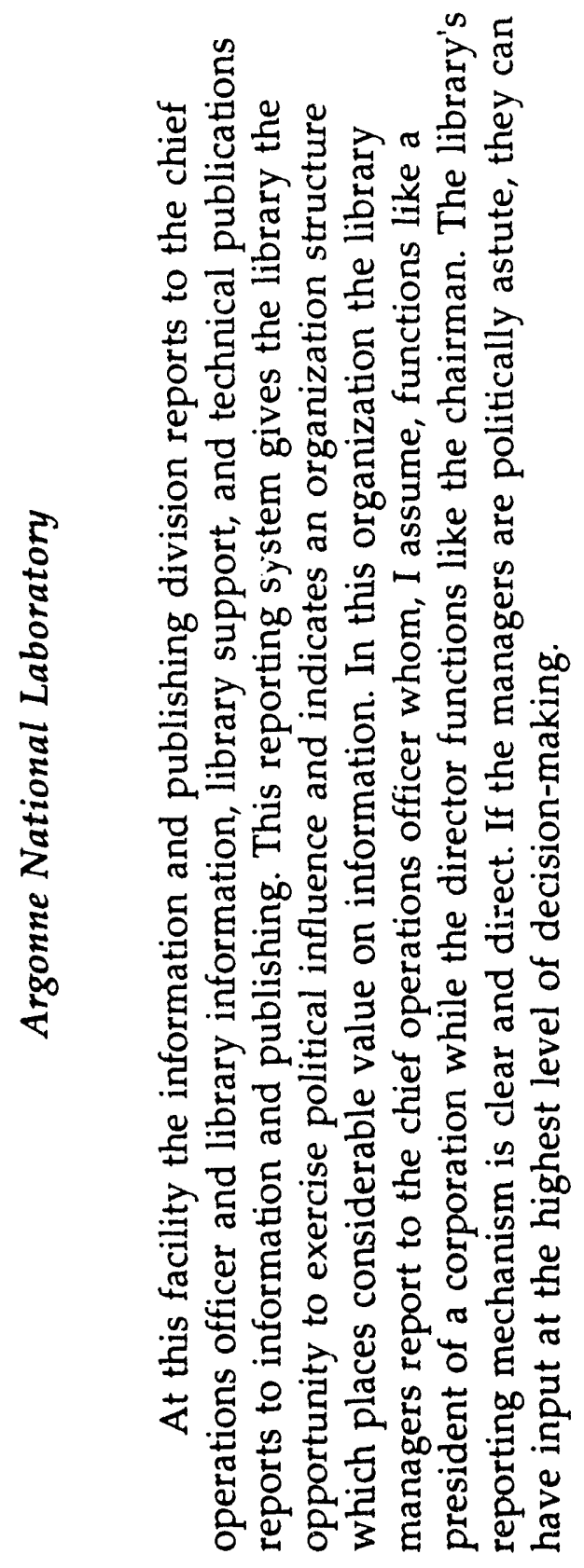




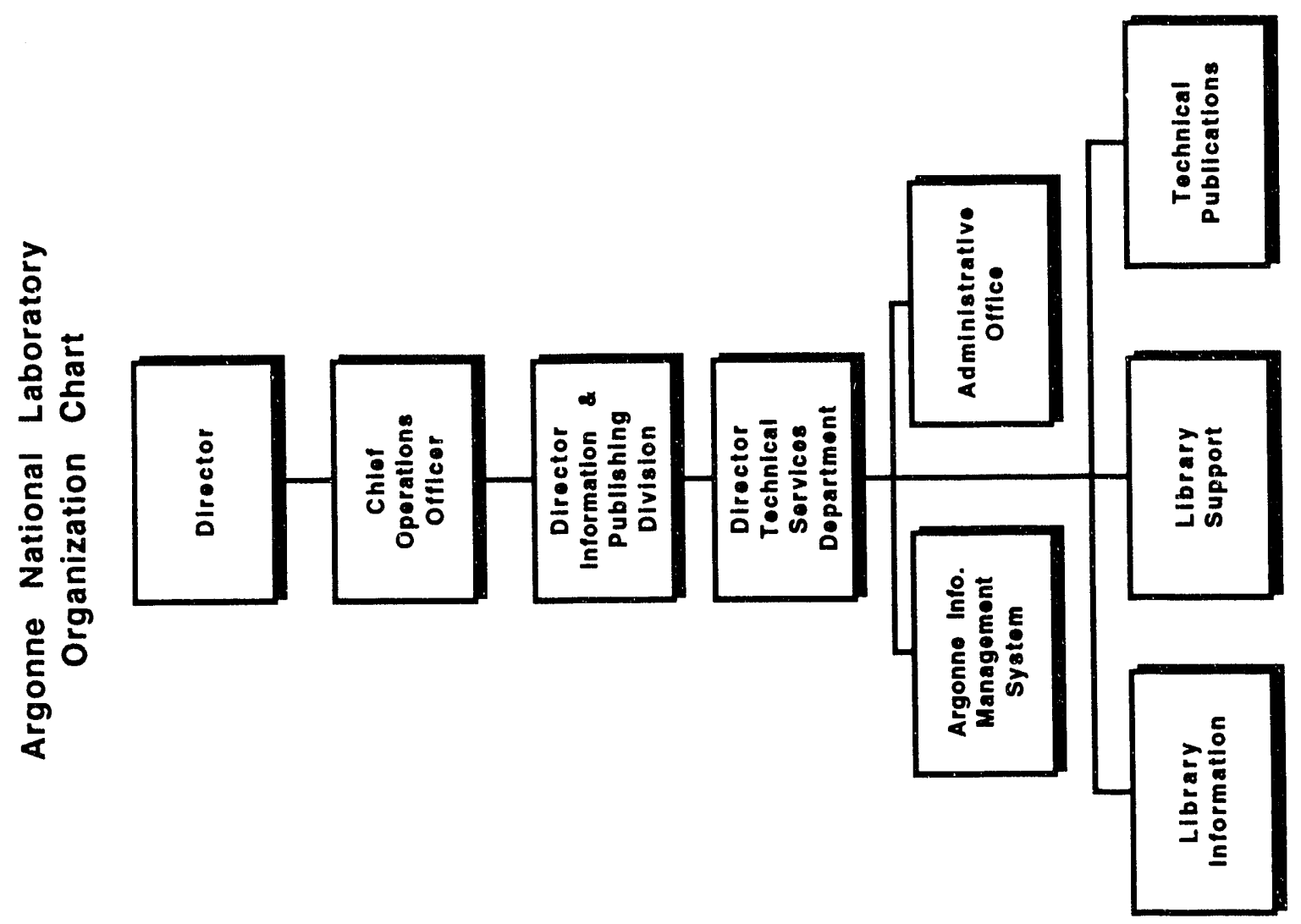




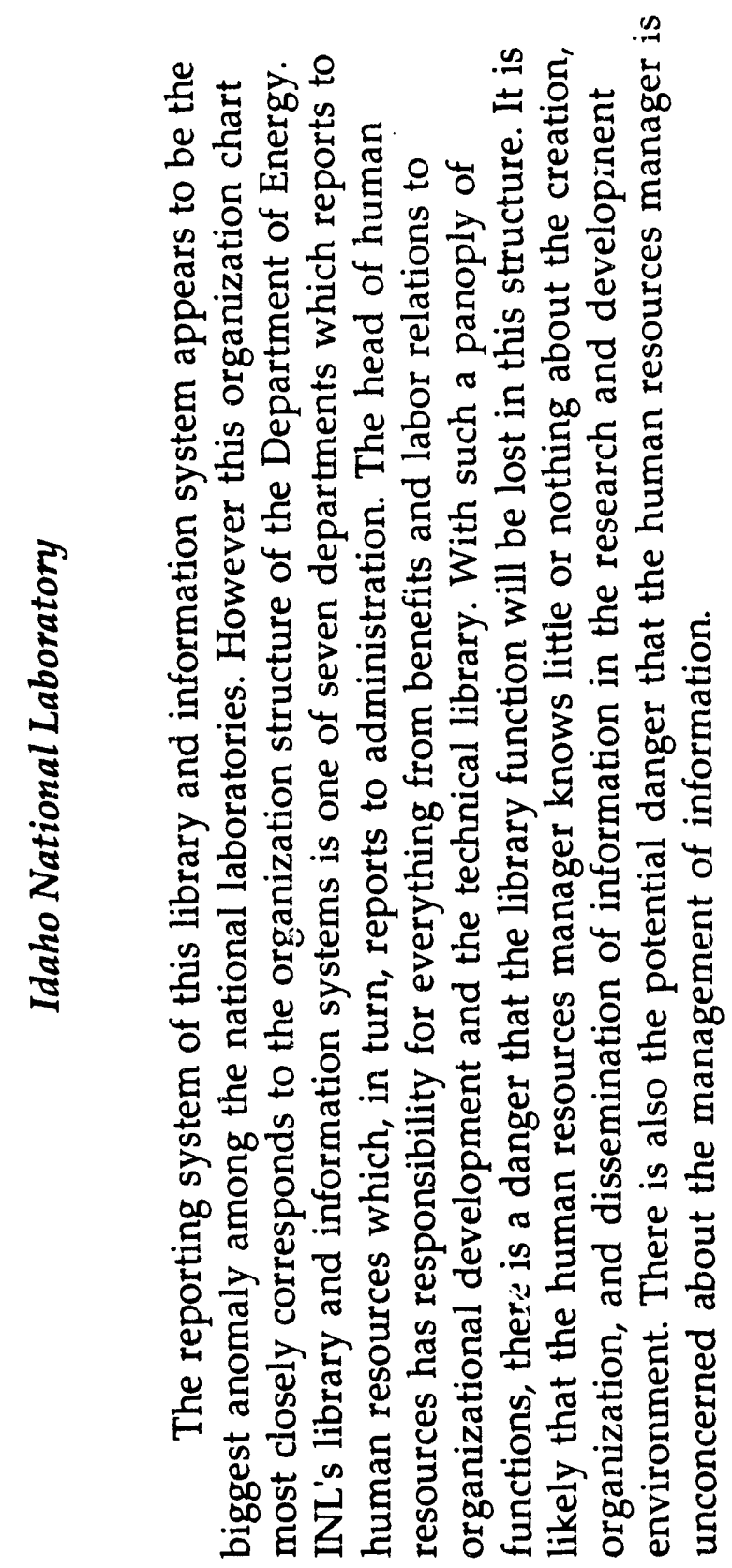




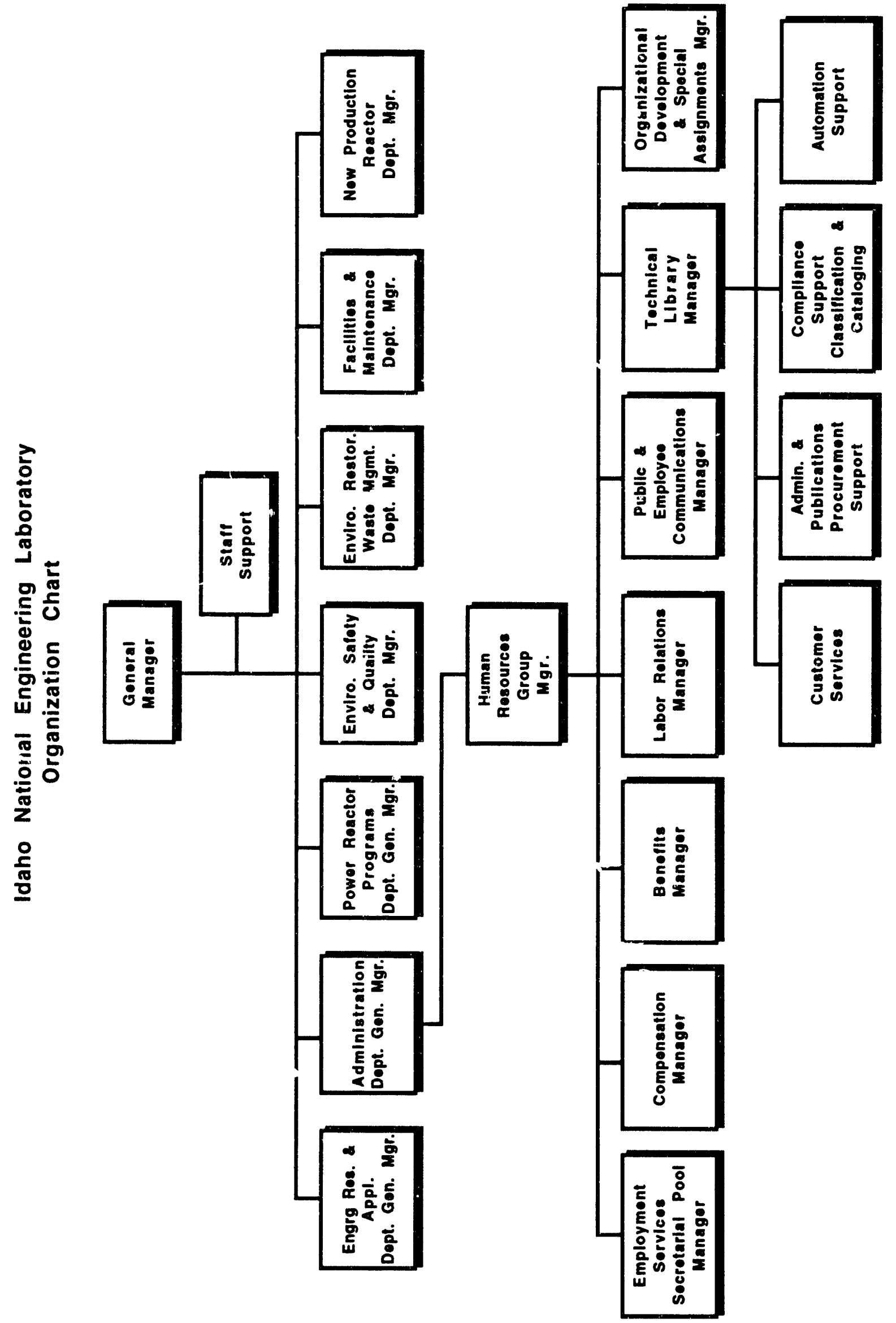




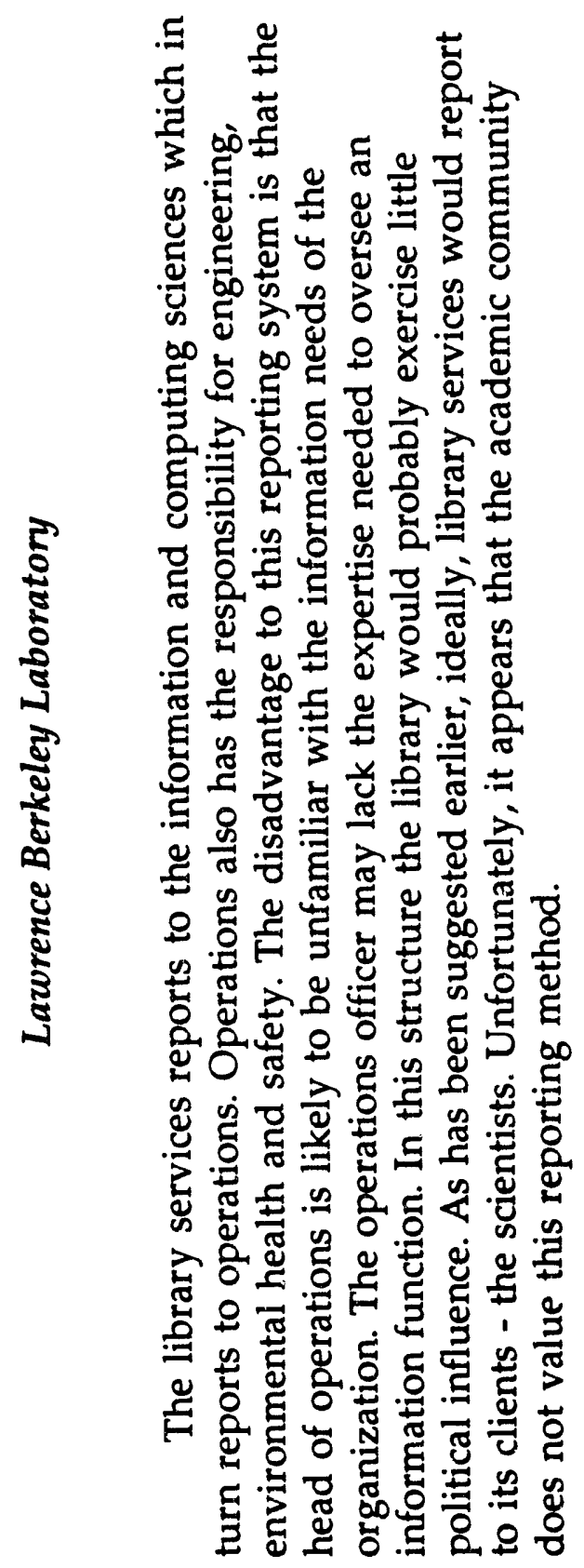




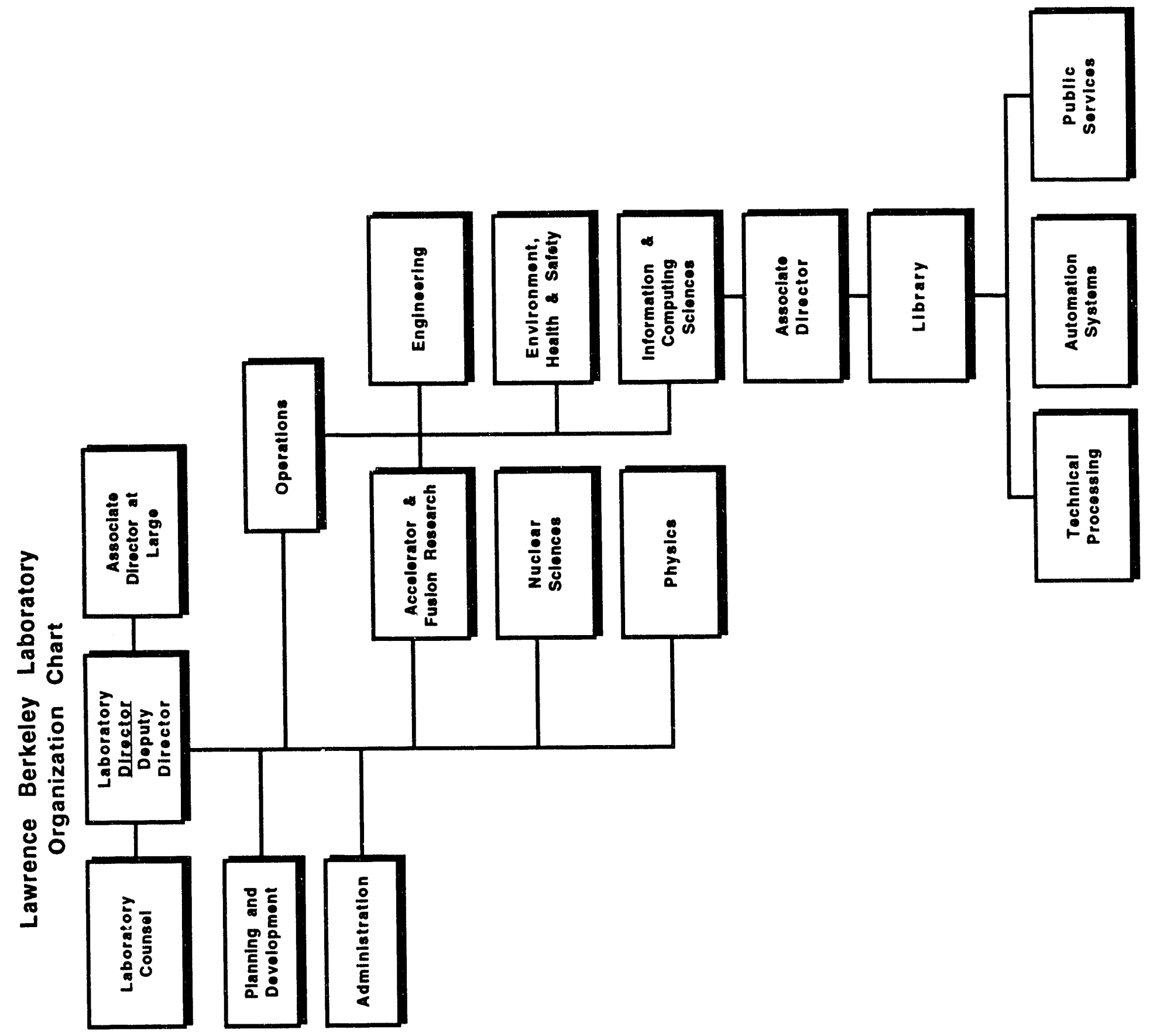




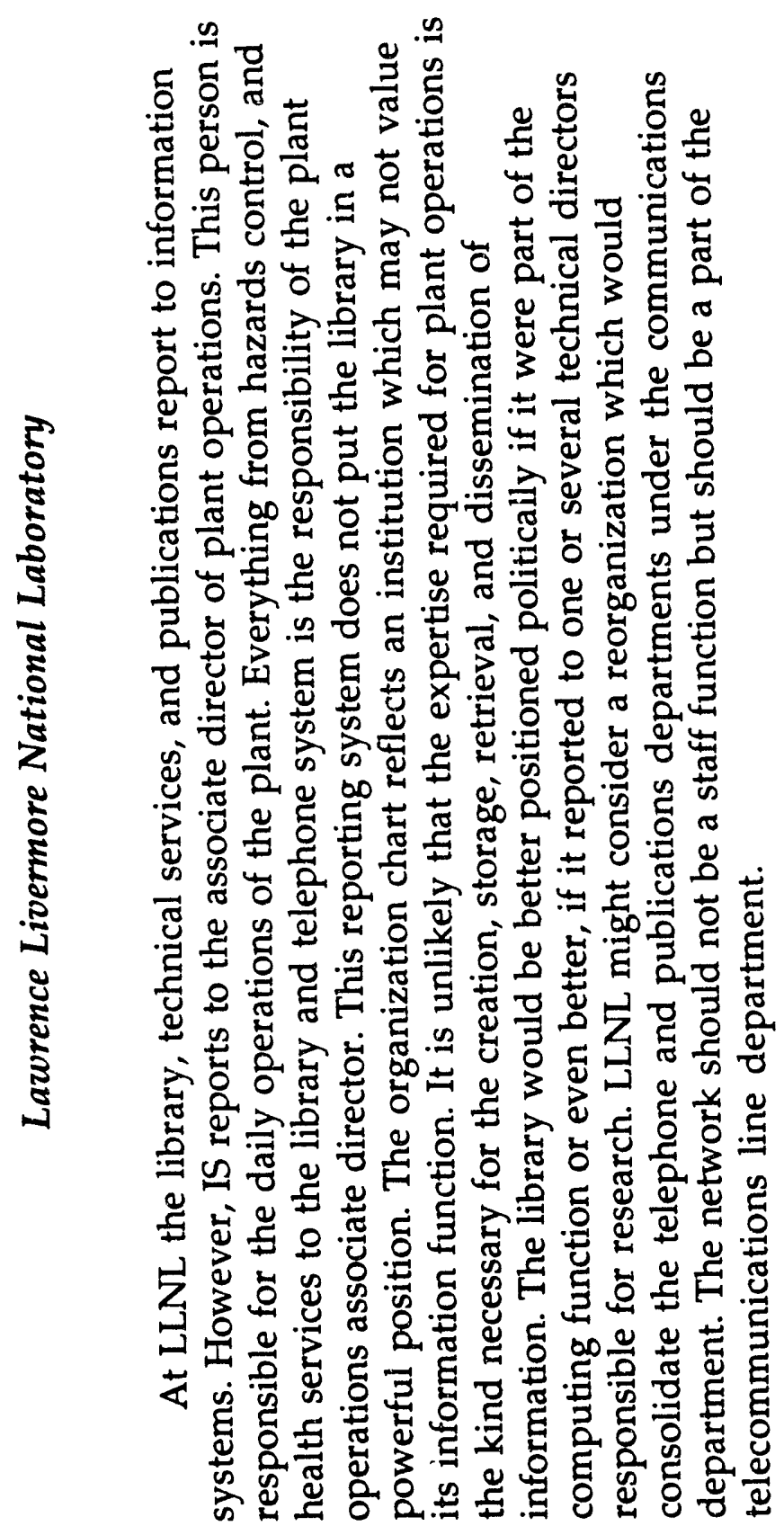




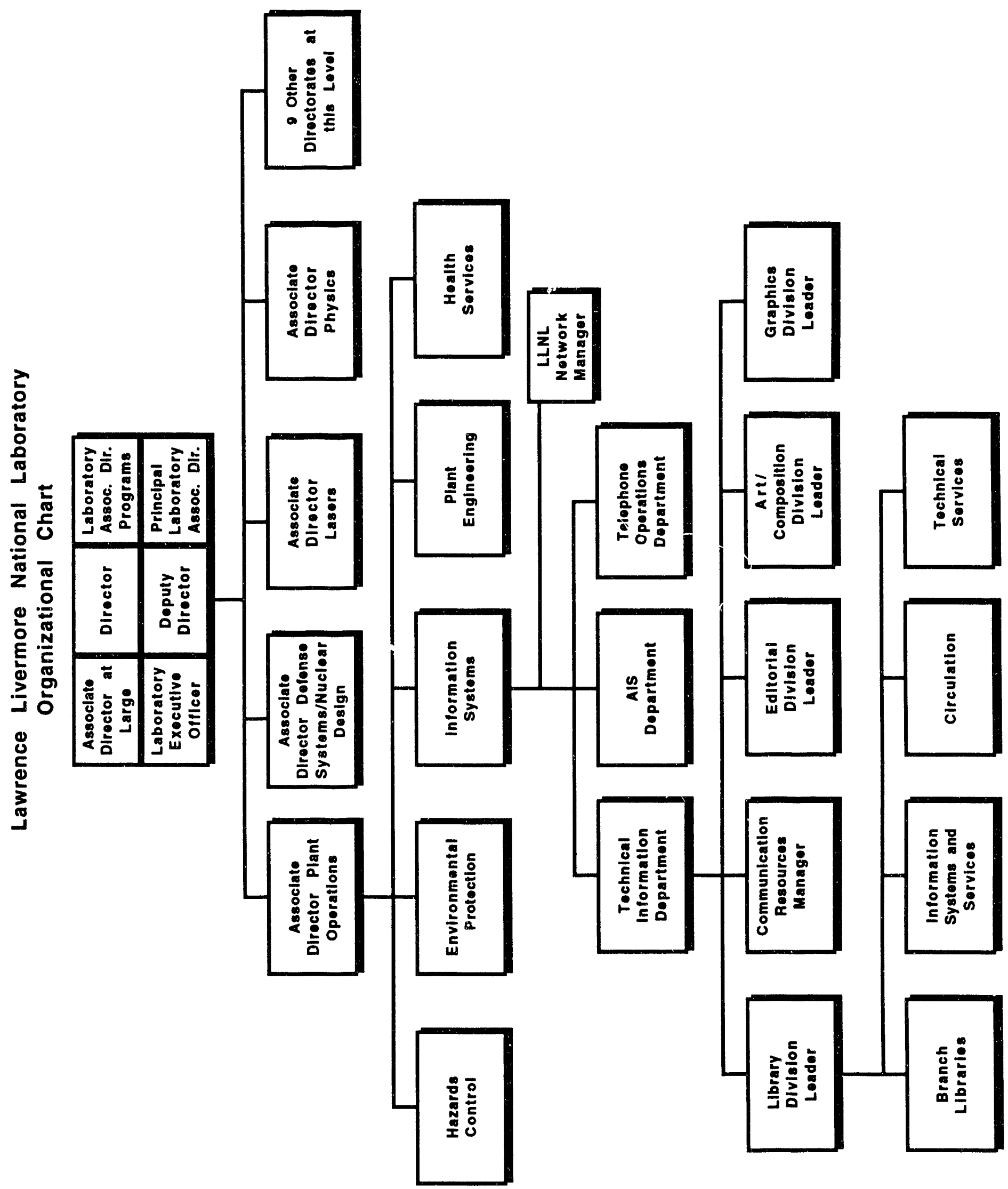




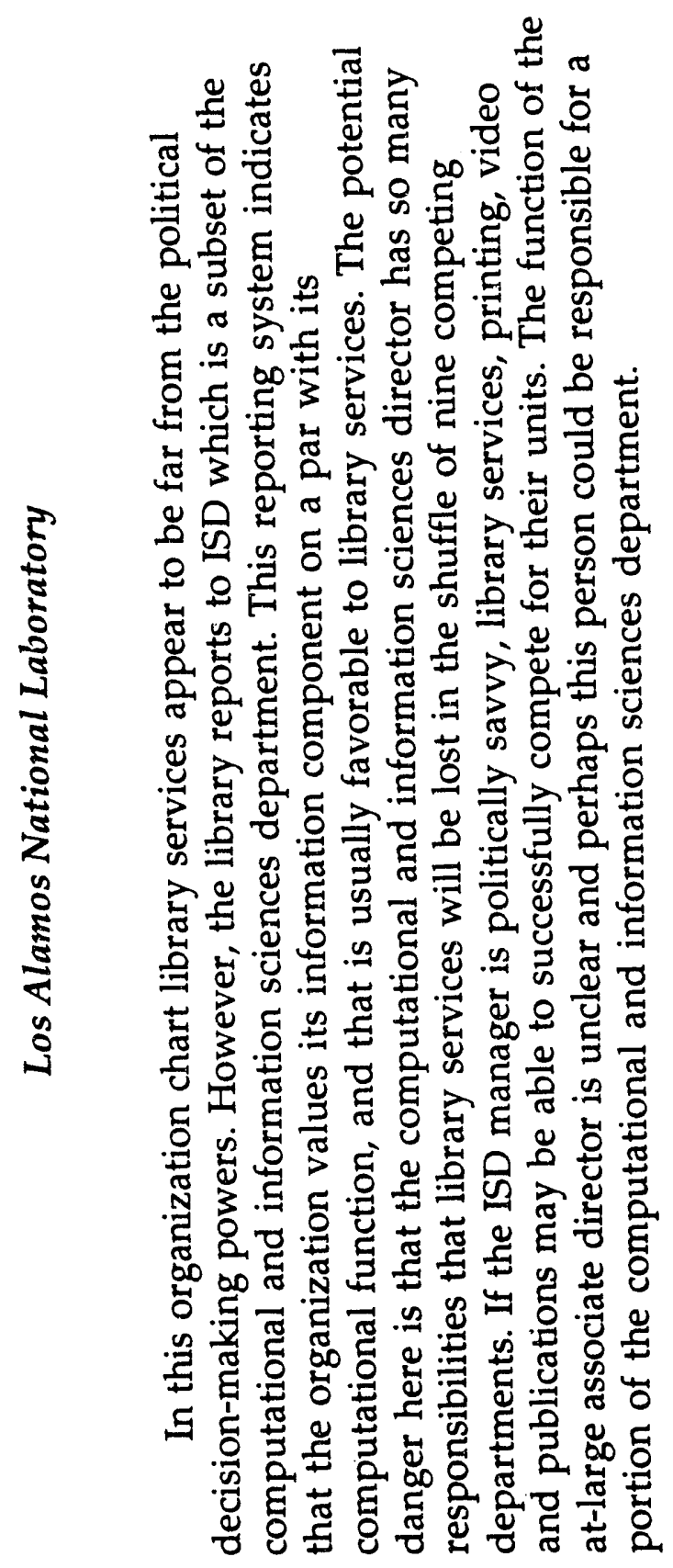




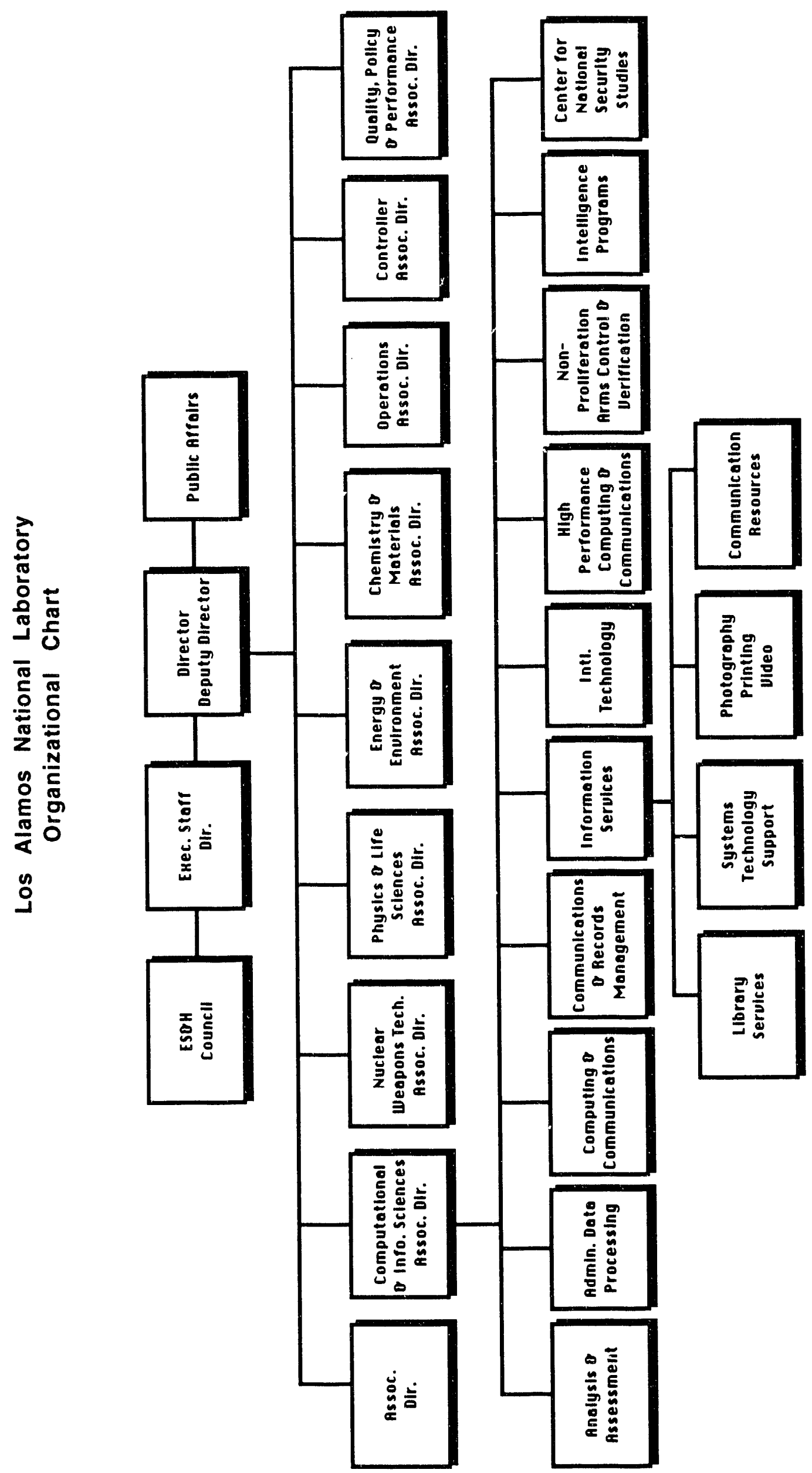




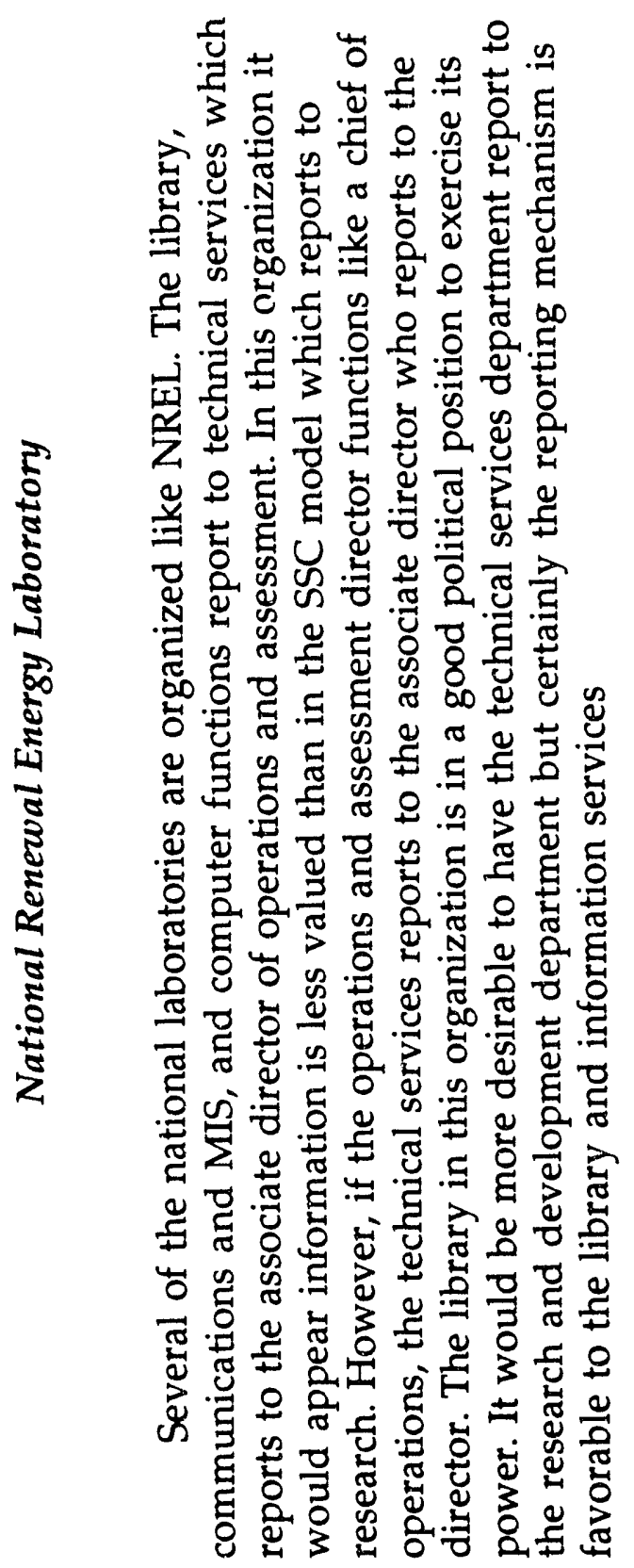









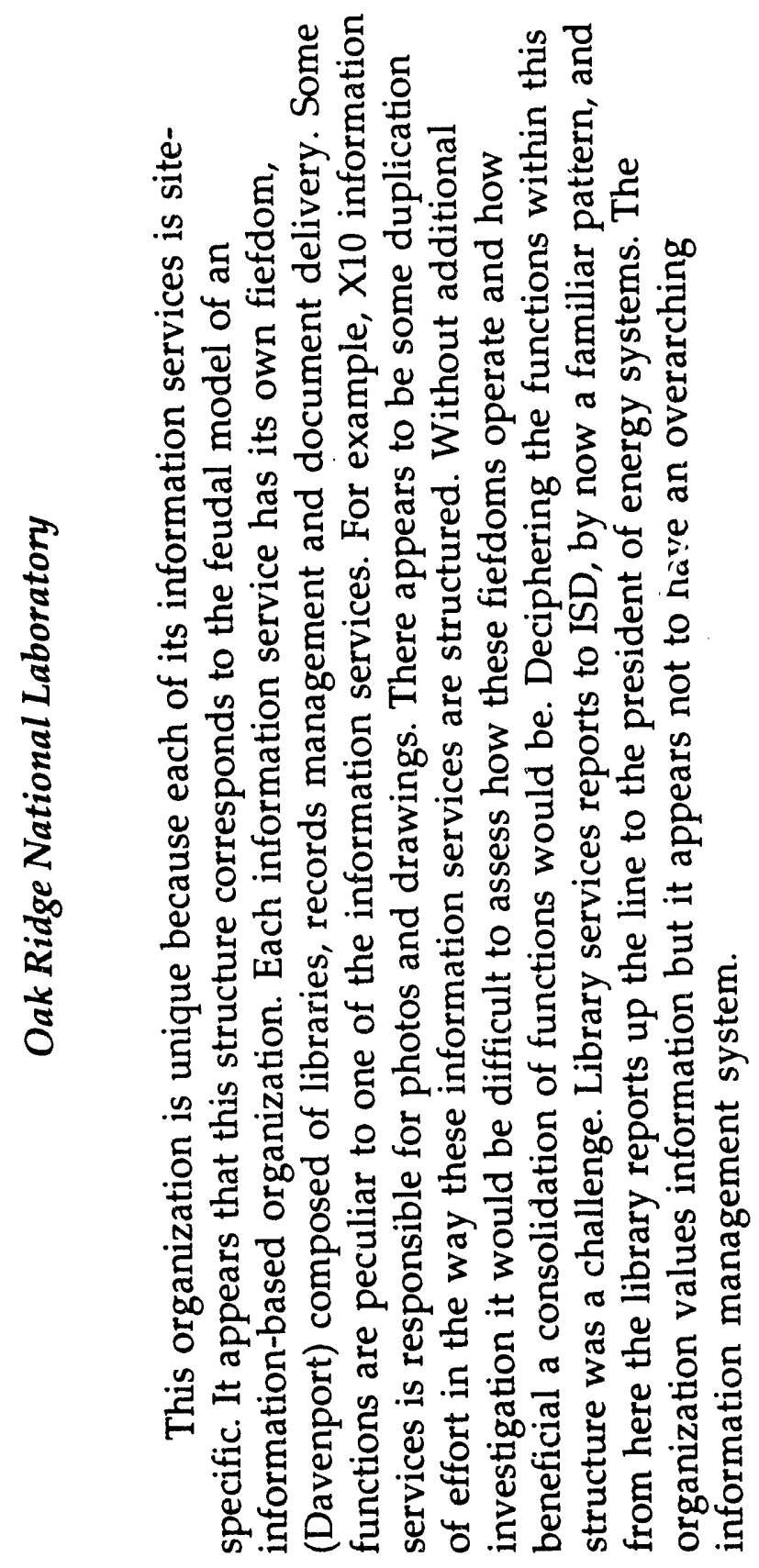




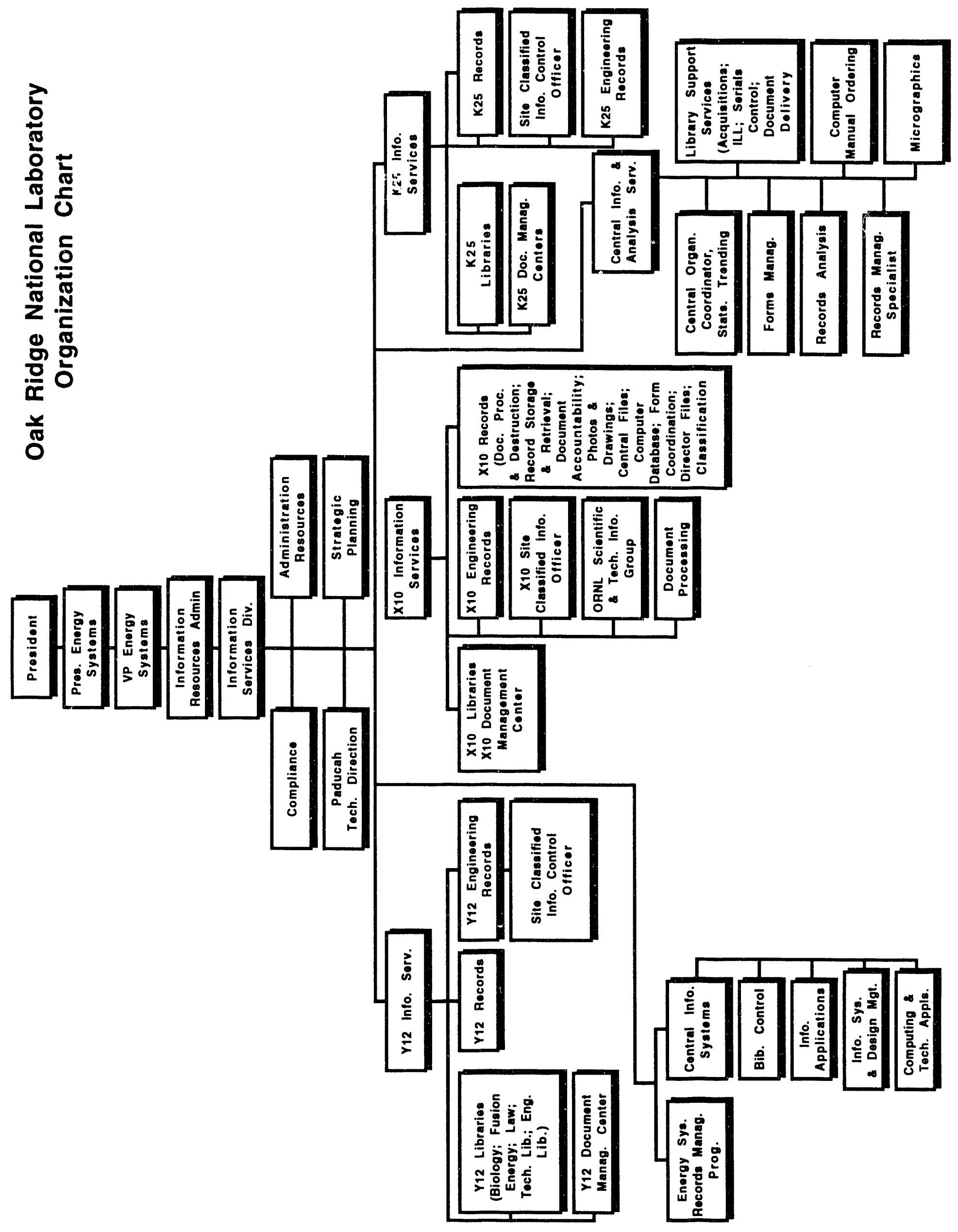




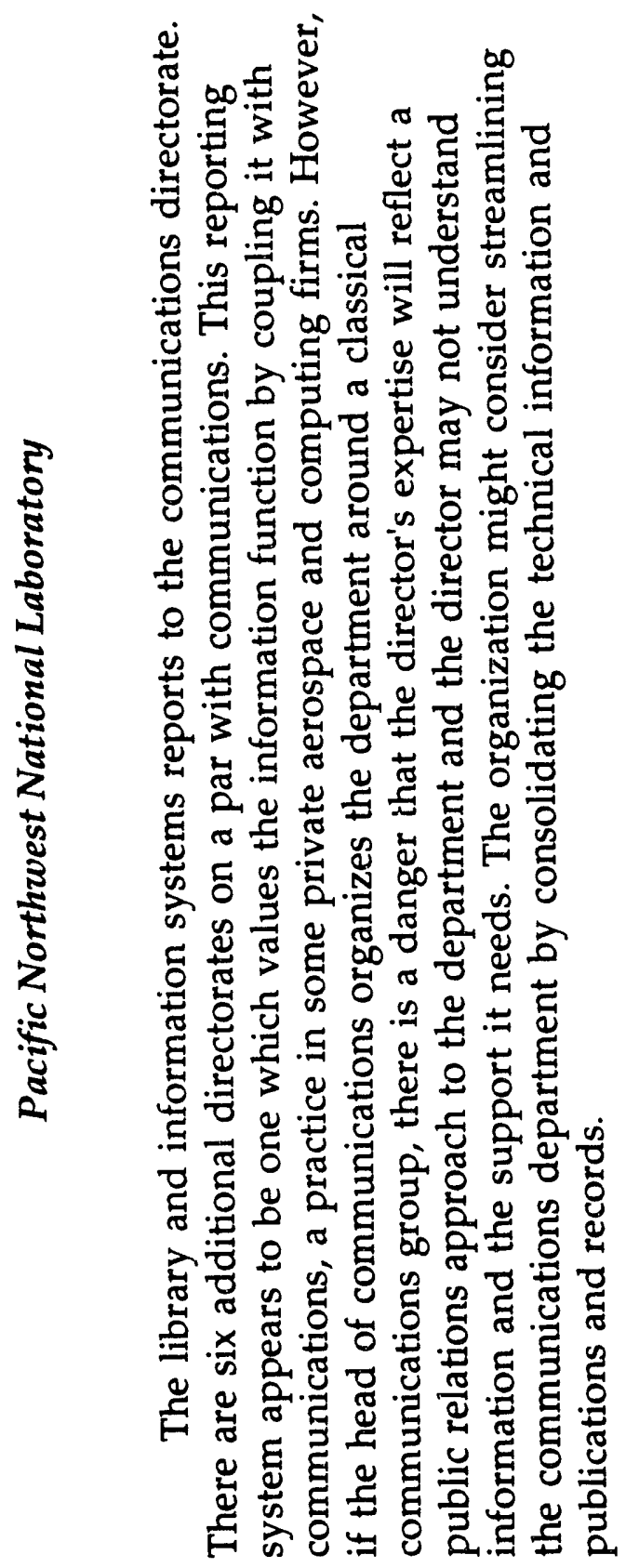




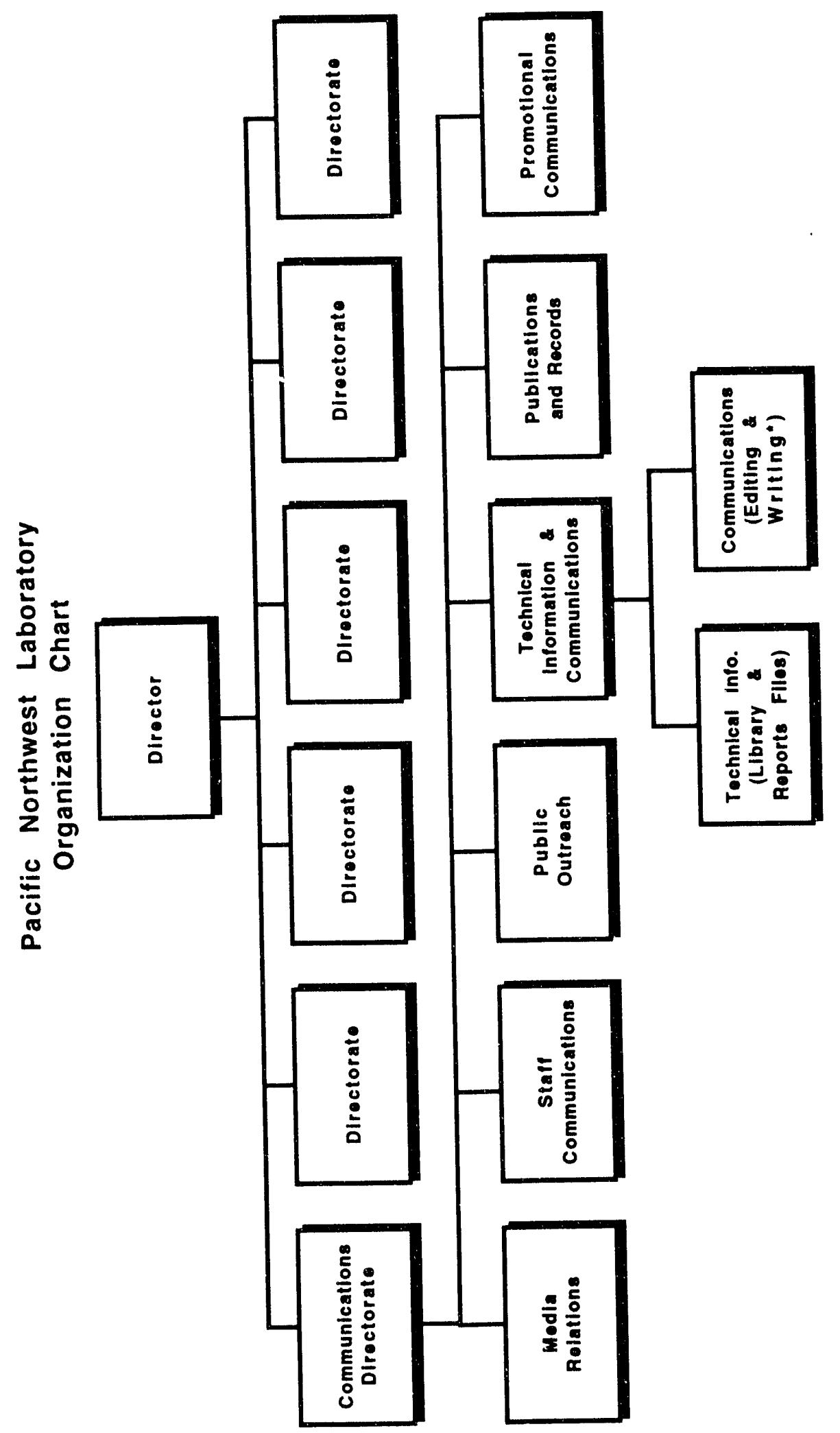

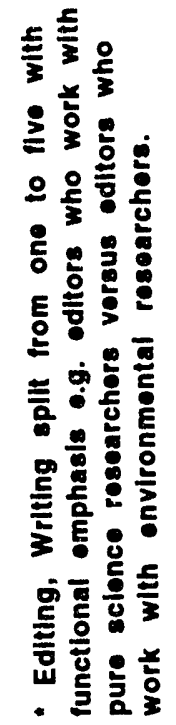




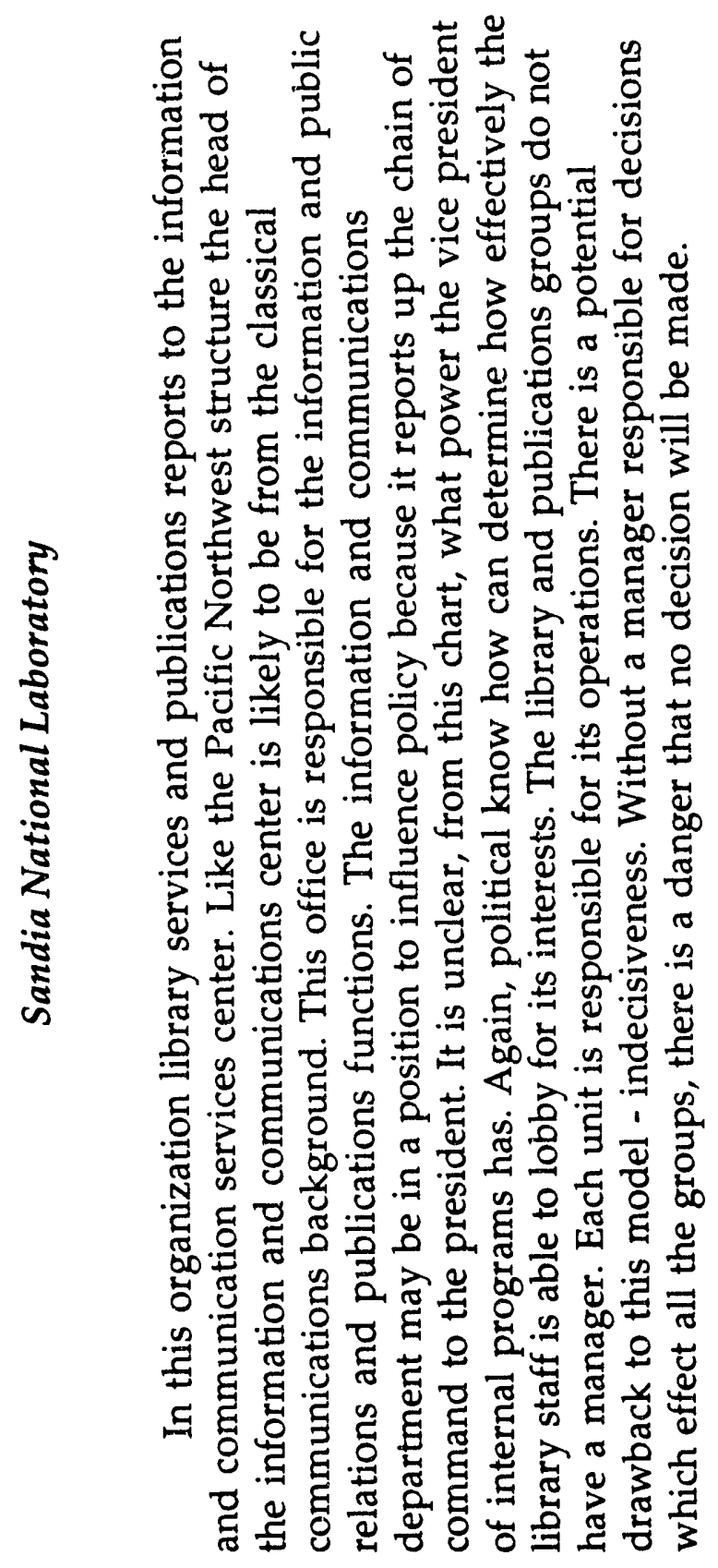




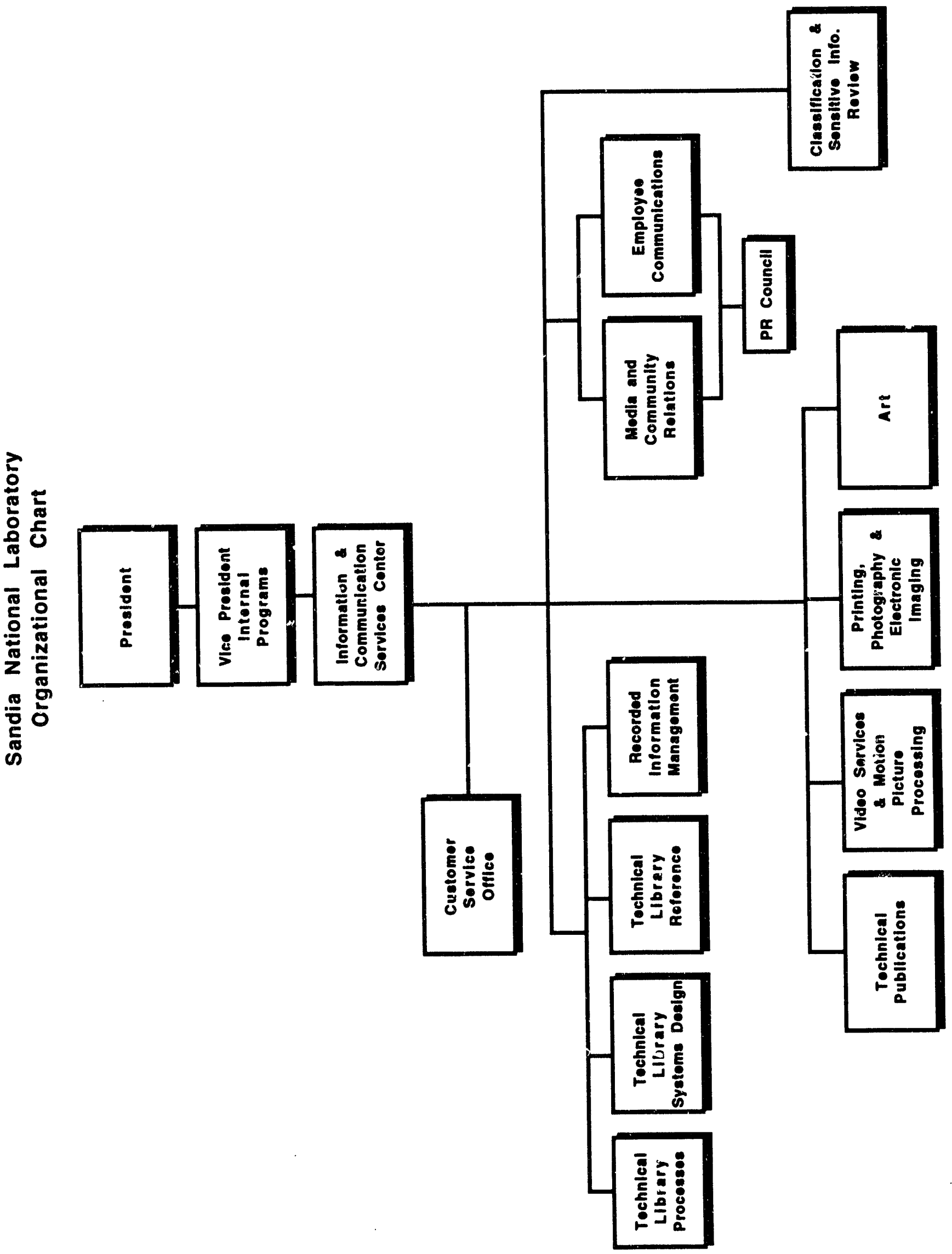




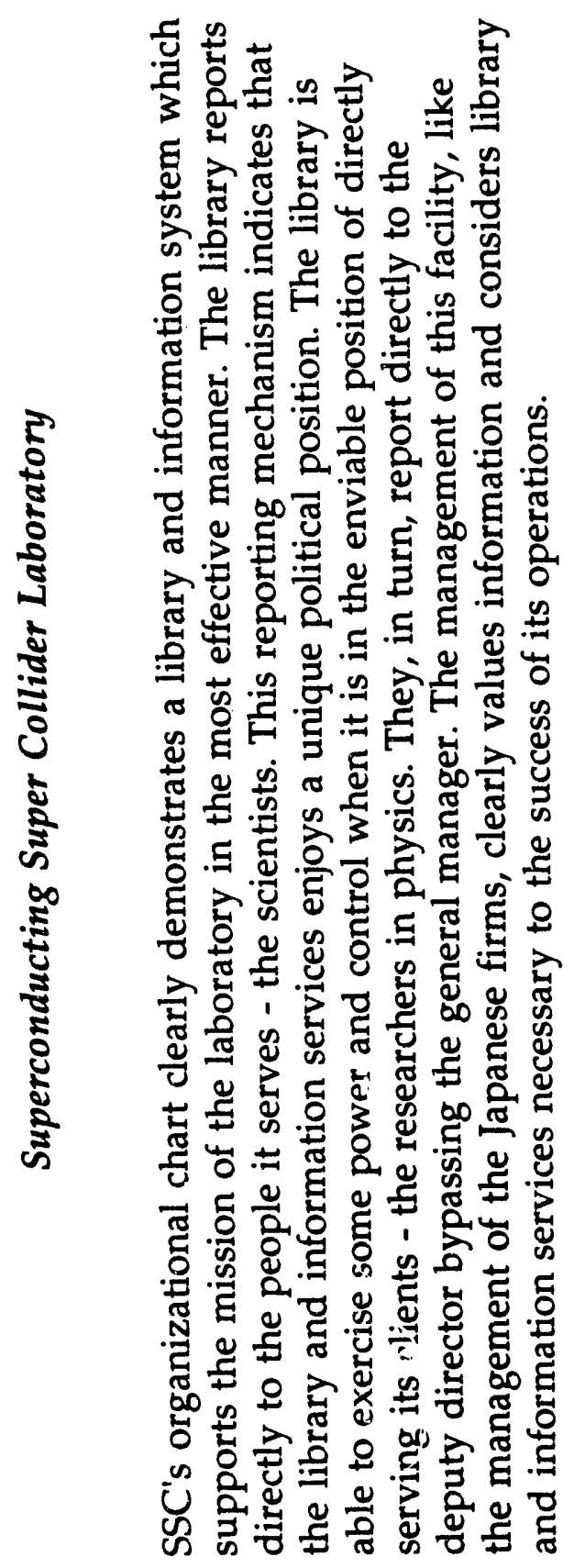




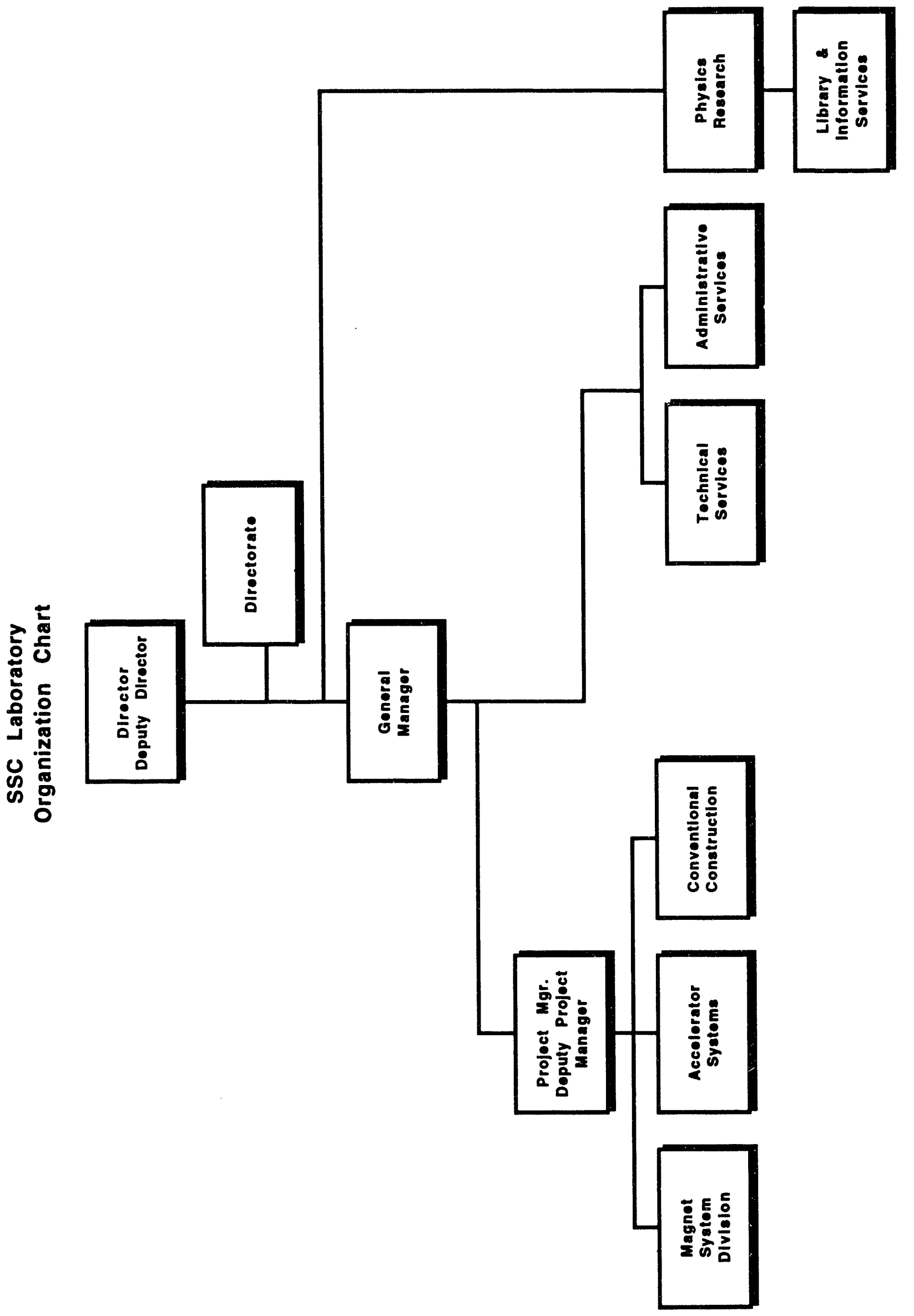




\section{Endnotes}

1. Moulik, Amal and Dennis Lai.

"Rebels in Search of Champions - Envisioning the Library of the Future."

Electronic Library, vol. 10, n.2, (1992 Apr): 97-102.

2. Prusak, Laurence and James Matarazzo.

"Information Management and Japanese Success."

Ernst \& Young Center for Information Technology and Strategy.

3. Davenport, Thomas, Robert G. Eccles, and Laurence Prusak.

"Information Politics."

Sloan Management Review, vol. 34, n.1, (1992): 53-65.

Special thanks to Janice Butler for her work in replicating the organization charts.

Special thanks to Rich Hunt for his assistance in overseeing the project. 

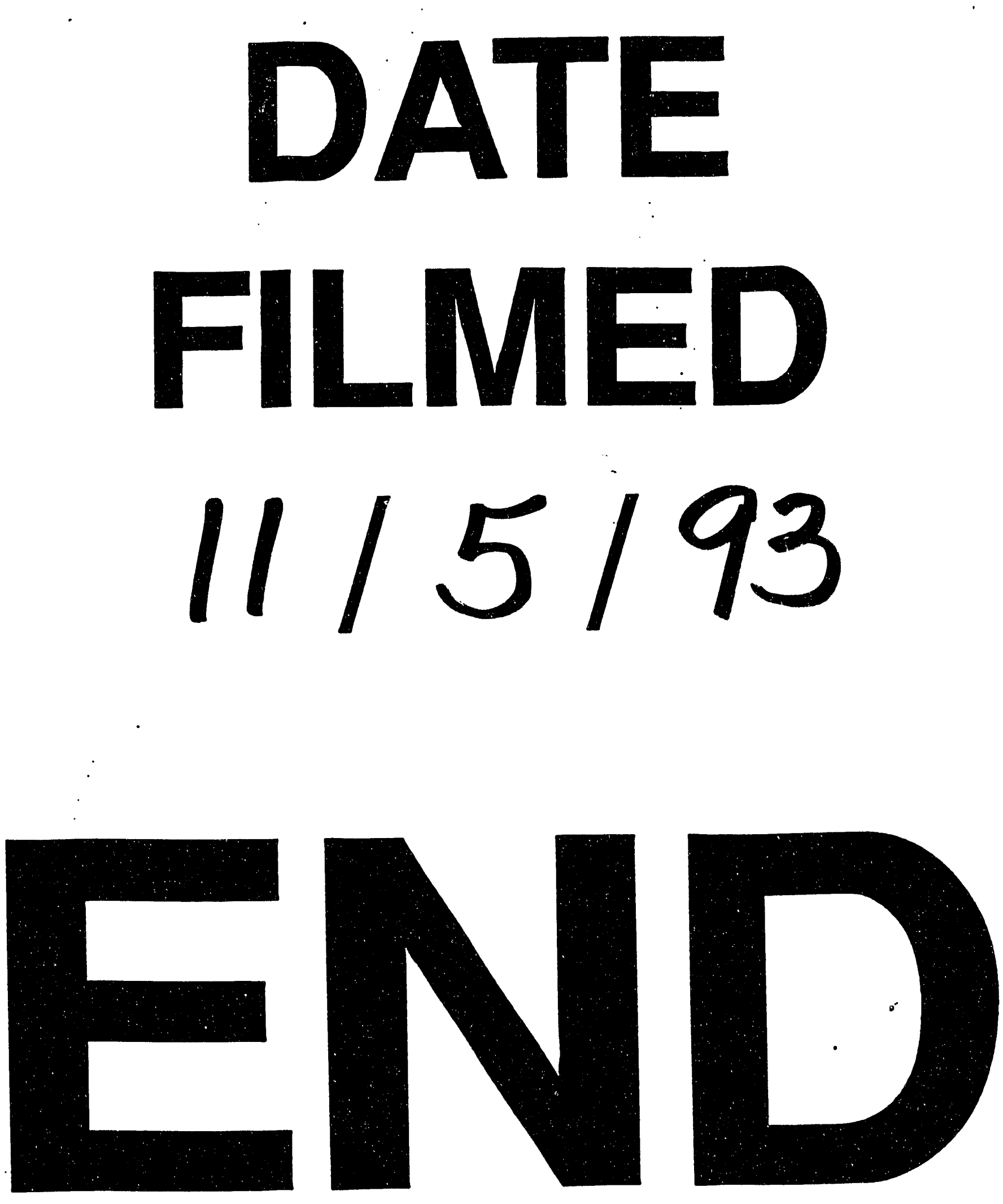
